\title{
ANALISIS PENGHITUNGAN, PENYETORAN DAN PELAPORAN PAJAK \\ PENGHASILAN PASAL 4 AYAT 2 MENGENAI PERUSAHAAN JASA \\ KONSTRUKSI ATAS BEBAN PAJAK
}

(Studi Kasus Pada DELTA GROUP)

Oleh : Nur Rachmah Wahidah, SE., M.M.

Dosen Prodi D-III Sekretari/Adm. Perkantoran Universitas Pamulang

nurrachmah32@gmail.com

\begin{abstract}
ABSTRAK
Tujuan yang ingin dicapai dari penelitian ini adalah untuk mengetahui perhitungan, penyetoran dan pelaporan pajak penghasilan pasal 4 ayat 2 mengenai perusahaan jasa konstruksi terhadap beban pajak yang dilakukan DELTA GROUP dengan sample menggunakan PT.DELTA KAHURIPAN dengan ketentuan mengenai penyetoran dan pelaporan pada pajak penghasilan pasal 4 ayat 2 yang ada pada UU no. 40 tahun 2009 sehingga dapat diketahui tingkat kesesuaiannya. Data penelitian diperoleh penulis melalui penelitian lapangan baik dengan cara observasi maupun wawancara serta didukung dengan penelitian pustaka. Metode analisis yang digunakan penulis adalah metode analisis deskriptif yang bersifat komparatif yaitu dengan cara mengumpulkan data dan informasi yang berkaitan dengan penerapan PPH pasal 4 ayat 2 pada obyek penelitian khususnya dalam hal penyetoran dan pelaporan kemudian melakukan analisis dan pebandingan terhadap prosedur tentang penyetoran dan pelaporan PPH pasal 4 ayat 2 yang terdapat dalam undang- undang no. 40 tahun 2009 tentang PPH pasal 4 ayat 2 atas jasa konstruksi. Dari hasil penelitian dapat disimpulkan bahwa penyetoran dan pelaporan Pajak Penghasilan pasal 4 ayat 2 atas jasa konstruksi yang dilakukan PT. DELTA KAHURIPAN belum seluruhnya sesuai dengan ketentuan undang-undang yang berlaku.
\end{abstract}

Kata Kunci : Penyetoran, Pelaporan, pajak penghasilan pasal 4 ayat 2 dan beban pajak

\section{PENDAHULUAN}

\section{Latar Belakang Masalah}

Pajak merupakan sumber dari pendapatan utama di Indonesia disamping sumber minyak bumi dan gas alam yang sangat penting peranannya bagi kelangsungan hidup bangsa Indonesia.Dana dari sektor pajak disamping digunakan untuk membiayai pembangunan juga berfungsi sebagai stabilisator untuk mencapai tingkat pertumbuhan ekonomi yang tinggi.Penerimaan sektor pajak dari tahun ke tahun selalu meningkat seiring dengan perkembangan dan kemajuan pembangunan di segala bidang. 
Dalam rencana kerja pemerintah tahun 2014 yang mempunyai muatan berupa tantangan utama pembangunan tahun 2014, yaitu membangun penyangga terhadap gejolak global, mempertahankan momentum percepatan pertumbuhan ekonomi yang sudah di capai, serta peningkatan kesejahteraan masyarakat melalui penurunan. kemiskinan,pengangguran,dan penanganan daerah tertinggal. Maka pemerintah terus meningkatkan penggalian potensipotensi dan terus mengoptimalkan serta mengembangkan sumber-sumber pendapatan nasional baik dari perpajakan maupun bukan pajak untuk tercapainya rencana kerja pemerintah tersebut agar pembangunan nasional dapat dilakukan dengan maksimal.

Pendapatan nasioal dari sektor perpajakan merupakan pendapatan nasional yang paling besar dan mempunyai peranan penting dalam Anggaran Pendapatan dan Belanja Negara (APBN), dimana setiap tahunnya realisasi penerimaan pajak mengalami peningkatan yang cukup signifikan,seperti di tahun 2013 penerimaan pajak sebesar Rp 1099 triliun,jumlah itu mencapai 96 persen dari target sebelumnya yaitu sebesar Rp 1.139,32 triliun, pada tahun 2012 penerimaan pajak sebesar Rp980,1 triliun dari target sebelumnya yaitu sebesar Rp 1.016 triliun,pada tahun 2011 penerimaan perpajakansebesar Rp 872,6 triliun atau mencapai 99,3\% dari target sebesar Rp 878,7 triliun dibandingkan dengan realisasi tahun 2010,maka realisasi penerimaan perpajakan tahun 2011 naik sebesar Rp 149,3 triliun atau mengalami pertumbuhan sebesar 20,6\% oleh karena itu pemerintah mematok pendapatan Negara dan hibah 2014, sebesar Rp. 1.667,1 triliun dimana $80 \%$ dari jumlah tersebut berasal dari sektor pajak.Pemerintah berharap pendapatan nasional dari penerimaan pajak tersebut dapat memperluas ruang gerak dalam membiayai pembangunan nasional.

Pajak penghasilan menduduki tempat yang sangat penting karena mempunyai peranan besar dalam Anggaran Pendapatan dan Belanja Negara (APBN) dan memberikan dampak yang besar dalam perekonomian rakyat Indonesia.

Sudah menjadi Ketentuan Umum dan Tata Cara Perpajakan (UU KUP) bahwa dalam Pajak Penghasilan (Pph) menggunakan Surat Pemberitahuan Masa artinya surat yang oleh wajib pajak digunakan untuk melaporkan perhitungan dan atau pembayaran pajak,objek pajak dan atau bukan objek pajak, dan atau harta dan kewajiban sesuai dengan ketentuan peraturan perundangundangan perpajakan,surat pemberitahuan masa dihitung tiap bulan.

Surat Pemberitahuan merupakan sarana wajib pajak untuk menetapkan atau menghitung sendiri besarnya pajak terutang. Fungsi Surat pemberitahuan bagi wajib pajak penghasilan adalah sebagai sarana untuk melaporkan dan mempertanggungjawabkan penghitungan jumlah pajak yang sebenarnya terutang dan untuk melaporkan tentang: 
1. Pembayaran atau pelunasan pajak yang telah dilaksanakan sendiri dan atau melalui pemotongan atau pemungutan pihak lain dalam 1 ( satu) tahun pajak atau bagian tahun pajak.

2. Penghasilan yang merupakan objek pajak dan atau bukan objek pajak.

3. Harta dan kewajiban.

4. Pembayaran dari pemotong atau pemungut tentang pemotongan atau pemungutan pajak orang pribadi atau badan lain dalam 1 ( satu) pajak sesuai dengan ketentuan peraturan perundang-undangan perpajakan.

Penelitian ini dilakukan pada perusahaan jasa yang bergerak di bidang konstruksi. Berbagai peraturan maupun Undang-Undang mengenai jasa konstruksi diatur khusus oleh Pemerintah. Hal tersebut disebabkan karena jasa konstruksi merupakan salah satu kegiatan dalam bidang ekonomi,sosial dan budaya yang mempunyai peranan penting dalam pencapaian berbagai sasaran guna menunjang terwujudnya tujuan Pembangunan Nasional. Peraturan perpajakan mengenai usaha jasa konstruksi juga diatur khusus, dalam hal ini pengenaan pajak atas usaha jasa konstruksi berbeda dengan wajib pajak badan pada umumnya. Sesuai dengan Undang-Undang Nomor 18 Tahun 1999 tentang Jasa Konstruksi, yang dimaksud dengan jasa konstruksi adalah layanan jasa konsultasi perencanaan pekerjaan konstruksi, layanan jasa pelaksanaan pekerjaan konstruksi, dan layanan jasa konsultasi pengawasan pekerjaan konstruksi. Sedangkan pekerjaan konstruksi adalah keseluruhan atau sebagian rangkaian kegiatan perencanaan dan atau pelaksanaan beserta pengawasan yang mencakup pekerjaan arsitektural, sipil, mekanikal, elektrikal dan tata lingkungan masing-masing beserta kelengkapannya, untuk mewujudkan suatu bangunan atau bentuk fisik lain.

\section{Identifikasi Masalah}

1. Penerapan penghitungan, penyetoran, pelaporan pajak penghasilan pasal 4 ayat 2 atas proyek jasa konstruksi pada Delta Group.

2. Kesesuaian penghitungan,penyetoran,pelaporan Pajak Penghasilan pasal 4 ayat 2 atas proyek jasa konstruksi pada Delta Group.

3. Penerapan pajak penghasilan pasal 4 ayat 2 atas beban pajak.

\section{Perumusan Masalah}


1. Bagaimana Penerapan penghitungan, penyetoran, pelaporan pajak penghasilan pasal 4 ayat 2 atas proyek jasa konstruksi pada Delta Group?

2. Bagaimana Kesesuaian penghitungan,penyetoran,pelaporan Pajak Penghasilan pasal 4 ayat 2 atas proyek jasa konstruksi pada Delta Group?

3. Bagaimanakah penerapan pajak penghasilan pasal 4 ayat 2 atas beban pajak?

\section{Kerangka Pemikiran}

Menurut Sugiyono (2009)Kerangka pemikiran adalah kegiatan penelitian,mulai dari tahap awal sampai tahap akhir harus merupakan urut-urutan logis dari pemikiran peneliti untuk memecahkan suatu masalah penelitian,yang dituangkan dalam bentuk bagan dengan penjelasannya. Adapun pengertian bagan yakni gambaran atau sketsa buram untuk memperlihatkan atau menerangkan sesuatu. Data maupun informasi yang ingin disampaikan direalisasikan melalui gambar. Bagan ada yang berbentuk diagram mempunyai bentuk yang beragam, antara lain: lingkaran, garis, pohon dan batang.

\section{Metode Pengumpulan Data}

Ada dua metode pengumpulan data yang digunakan dalam penulisan Penelitian ini yaitu sebagai berikut:

1. Penelitian pustaka

Kepustakaan merupakan bahan utama dalam penelitian sekunder, penelitian data sekunder memerlukan cara agar penelitian sekunder dapat dilakukan lebih cepat dan efisien. Penelusuran data sekunder dilakukan dengan dua cara, yaitu penelusuran secara manual dan penelusuran secara komputer (indriantoro, nur, dan bambang, 2002:150) penulis memperoleh informasi yang berkaitan dengan masalah yang sedang diteliti yang berasal dari buku, jurnal, internet, dan perangkat lain yang berkaitan dengan judul penelitian

2. Penelitian lapangan

a. Metode Observasi

Observasi merupakan proses pencatatan pola perilaku subyek, obyek atau kejadian yang sistematis tanpa adanya pertanyaandan komunikasi dengan individu-individu 
yang diteliti. Dalam penelitian ini penulis melakukan observasi langsung ke PT. DELTA GROUP untuk pengambilan dan obyek penelitian.

b. Wawancara

Wawancara merupakan teknik pengumpulan data dalam metode survey yang menggunakan pertanyaan secara lisan kepada subyek penelitian (indriantoro, nur, dan bambang, 2002:152). Wawancara dilakukan kepada bagian keuangan dan administrasi dengan memberikan pertanyaan mengenai kebijakan perusahaan dalam masalah perpajakannya terutama tentang penjualan jasa kontruksi sehingga mendapatkan jawaban dari pertanyaan yang diajukan oleh penulis.

\section{Metode Analisa Data}

Metode analisis data yang digunakan dalam penelitian ini adalah metode analisis deskriptif kualitatif karena memberikan fakta dari prosedur atau kejadian yang terjadi dengan tujuan untuk membuat gambaran secara sistematis dan akurat serta sesuai dengan tujuan penelitian yaitu untuk menguraikan, menjelaskan, dan menegaskan peraturan-peraturan yang berhubungan dengan perhitungan, pencatatan, pembayaran dan pelaporan dalam SPT Masa Pph Pasal 4 ayat 2 atas jasa Konstruksi. Dari data yang telah dikumpulkan oleh penulis baik secara langsung maupun tidak langsung akan dijelaskan guna memperolehjawaban atas rumusan masalah yang ada.

Analisa yang digunakan dalam menjabarkan penelitian ini adalah:

1. Analisa kualitatif, yaitu analisa dengan cara mempelajari dalam menguji apakah ketentuanketentuan yang berlaku telah ditetapkan oleh perusahaan.

2. Analisa kuantitatif, yaitu analisa atas hasil penelitian dengan menggunakan perhitungan angka-angka. Analisa ini dilakukan untuk memperoleh data-data mengenai perhitungan serta pelaporan pajaknya.

Sumber data yag berkaitan langsung dengan penelitian ini adalah: 
1. Bagian keuangan perusahaan, untuk mendapatkan data mengenai pelaporan pajak perusahaan untuk tahun 2011 sampai dengan tahun 2013.

2. Pihak direksi atau pejabat perusahaan yang berwenang, sebagai perwakilan perusahaan untuk diwawancarai dalam rangka mengetahui kebijakan-kebijakan yang berlaku di perusahaan.

\section{Operasi Variabel Penelitian}

Sudjana dan Ibrahim (2001:23) menyatakan variabel penelitian dapat dikatakan sebagai atribut dari suatu individu, objek, gejala dan peristiwa tertentu yang dapat diukur secara kualitatif dan kuantitatif.

Dalam penelitian ini penulis mengidentifikasi variabel-variabel yang digunakan dalam membahas masalah tersebut, variabel utama yang berkenaan dengan topik pembahasan dalam Penelitian ini merupakan variabel tunggal yang terdiridari sub variabel antara lain:

1. Jasa kena pajak

Jasa Kena Pajak adalah setiap kegiatan pelayanan yang berdasarkan suatu perikatan atau perbuatan hukum yang menyebabkan suatu barang atau fasilitas atau kemudahan atau hak tersedia untuk dipakai, termasuk jasa yang dilakukan untuk menghasilkan barang karena pesanan atau permintaan dengan bahan dan atas petunjuk dari pemesan, yang dikenakan Pajak Pertambahan Nilai(UU No. 40 Tahun 2009 Pasal 1 angka 5).

2. Pencatatan Pajak Penghasilan Pasal 4 ayat 2

Yaitu Pajak atas penghasilan dengan perlakuan tersendiri yang diatur melalui peraturan pemerintah.Pajak ini sering disebut juga dengan Pajak penghasilan Final atau bersifat rampung sehingga pajak yang telah dipotong atau dipungut oleh pihak lain tidak dapat diperhitungkan atau dikreditkan oleh Wajib Pajak ketika melaporkan pajaknya yang terutang dalam SPT tahunan pada akhir tahun. ( Ivan, Billy, 2010 :261).

3. Usaha Jasa Konsruksi 
Yaitu layanan jasa konsultasi perencanaan pekerjaan konstruksi, layanan jasa pelaksanaan pekerjaan konstruksi, dan layanan jasa konsultasi pengawasan pekerjaan konstruksi.( Ivan, Billy, 2010: 287)

4. Penghitungan besarnya Pajak Penghasilan Pasal 4 ayat 2

Yaitu atas penghasilan dari usaha jasa Konstruksi dikenakan Pajak Penghasilan yang bersifat final dengan tarif pajak:

a. $2 \%$ dikali jumlah pembayaran atau penerimaan pembayaran tidak termasuk PPN, untuk Pelaksanaan Kontruksi yang dilakukan oleh Penyedia Jasa yang memiliki kualifikasi usaha kecil. $4 \%$ dikali jumlah pembayaran atau penerimaan pembayaran tidak termasuk PPN, untuk pelaksanaan konstruksi yang dilakukan oleh penyedia jasa yang tidak memiliki kualifikasi usaha.

b. $3 \%$ dikali jumlah pembayaran atau penerimaan pembayaran tidak termasuk PPN, untuk Pelaksanaan Konstruksi yang dilakukan oleh penyedia jasa selain penyedia jasa yang memiliki kualifikasi usaha menengah atau kualifikasi usaha besar.

c. $4 \%$ dikali jumlah pembayaran atau penerimaan pembayaran tidak termasuk PPN, untuk perencanaan konstruksi atau pengawasan konstruksi yang dilakukan oleh penyedia jasa yang memiliki kualifikasi usaha

d. $6 \%$ dikali jumlah pembayaran atau penerimaan pembayaran tidak termasuk PPN, untuk perencanaan konstruksi atau pengawasan konstruksi yang dilakukan oleh penyedia jasa yang tidak memiliki kualifikasi usaha.

\section{Penyetoran}

Subjek pajak melakukan penyetoran pajak terutang ke Bank penerima setoran pajak dengan melampirkan formulir Surat Setoran Pajak yang tersedia gratis di Kantor-kantor Pelayanan Pajak dan Kantor-kantor Penyuluhan Pajak di seluruh Indonesia paling lama tanggal 10 bulan berikutnya setelah berakhirnya Masa Pajak dan sebelum SPT Masa Pajak Penghasilan pasal 4 ayat 2 disampaikan.

6. Pelaporan 
Subjek pajak melakukan pelaporan pajak terutang dengan melampirkan dokumen Bukti potong pada setiap lampiran SPT dalam satu Masa Pajak adalah SPT Masa Pph pasal 4 ayat 2 dalam bentuk formulir kertas ke Kantor Pelayanan Pajak (KPP) paling lama tanggal 20 bulan berikutnya setelah berakhirnya Masa Pajak

Pada penelitian ini yang merupakan variabel bebas adalah analisis perhitungan, penyetoran dan pelaporan pajak jasa konstruksi, sedangkan variabel terikatnya adalahbeban pajak pada PT. DELTA KAHURIPAN.Dimana analisa yang dilakukan adalah penghitungan, penyetoran dan pelaporan pajak konstruksisehingga hasilnya akan terlihat apakah variabel tersebut berhubungan atau berpengaruh atau tidak terhadap beban pajak pada PT.DELTA KAHURIPAN.

Dalam penelitian ini onsep-konsep yang ada dioperasioanlkan sebagai berikut :

Variabel X1 : Perhitungan, Penyetoran dan Pelaporan

Variabel X2 : Pajak Konstruksi

Variabel Y : : Beban Pajak

\section{PEMBAHASAN DAN HASIL}

\section{Penerapan Penghitungan, Penyetoran Dan Pelaporan Pajak Penghasilan Pasal Ayat 2 Atas Jasa Konstruksi Pada DELTA GROUP}

Dari hasil penelitian yang telah dilakukan, ditemukan kesalahan penerapan penghitungan, penyetoran dan pelaporan Pajak Penghasilan Pasal 4 ayat 2.

1. Pembayaran imbalan jasa konstruksi yang dilakukan kontraktor berbadan hukum terutang PPh Pasal 23 sesuai dengan Peraturan Pemerintah No. 40 tahun 2009 atas perubahan Peraturan Pemerintah No. 51 Tahun 2008 per tanggal 1 Agustus 2008, pelaksanaan konstruksi yang dilakukan penyedia jasa yang berkualifikasi usaha menengah dan besar dikenakan tarif 3\% dan bersifat final. Akan tetapi, pada kenyataan Delta Group masih dikenakan tarif sebesar $2 \%$ atas jasa pelaksanaan konstruksi. Hal ini terjadi karena perusahaan masih diklasifikasikan sebagai pengusaha kena pajak kualifikasi usaha kecil sehingga masih dikenakan tarif $2 \%$ atas penghasilan kena pajak atas jasa konstruksi.Besarnya tarif $2 \%$ yang dikenakan atas jasa pelaksanaan konstruksi berlaku 
untuk jasa konstruksi dengan nilai pengadaan satu miliar ( 1 miliar ), sedangkan perusahaan atau subcont termasuk ke dalam pengusaha jasa konstruksi dengan kualifikasi usaha non kecil dengan nilai pengadaan di atas satu miliar ( 1 miliar ) lebih.

2. Kesalahan dalam penerapan tarif atas kegiatan jasa pelaksana konstruksi mengakibatkan pajak penghasilan pasal 4 ayat 2 menjadi kurang bayar. Dalam hal ini, Delta Group harus menyetorkan pajak kurang bayar tersebut sebelum terjadi pemeriksaan pajak dan sebelum dikeluarkannya Surat Ketetapan Pajak Kurang Bayar (SKPKB ) yaitu surat ketetapan pajak yang menentukan besarnya jumlah pokok pajak, jumlah kredit pajak, jumlah kekurangan pembayaran pokok pajak, besarnya sanksi administrasi dan jumlah pajak yang masih harus dibayar, besarnya administrasi dan jumlah pajak yang masih harus dibayar (Pasal $1 \mathrm{UU}$ KUP).Ketentan mengenai SKPKB diatur dalam Pasal 13 UU KUP.

3. PPh final jasa konstruksi dilakukan pada saat pembayaran atau cash basis. Hal ini sesuai dengan ketentuan Pasal 4 ayat (2) PMK Nomor 187/PMK.03/2008. 


\section{Penyetoran dan Pelaporan Pajak Penghasilan Pasal 4 ayat 2 periode 2011}

\begin{tabular}{|c|c|c|c|c|c|}
\hline No & Bulan & DPP & \begin{tabular}{|c|} 
PPH Pasal 4 \\
ayat 2 atas \\
jasa konstruksi
\end{tabular} & Tgl Setor & Tgl lapor \\
\hline 1. & Januari & 1.061 .215 .033 & 24.603 .322 & $03 / 02 / 2011$ & $18 / 02 / 2011$ \\
\hline 2. & Februari & 1.943 .213 .470 & 40.181 .349 & $04 / 03 / 2011$ & $14 / 03 / 2011$ \\
\hline 3. & Maret & 2.230 .462 .924 & 47.710 .292 & $11 / 04 / 2011$ & $20 / 04 / 2011$ \\
\hline 4. & April & 1.782 .838 .173 & 36.089 .916 & $09 / 05 / 2011$ & $16 / 05 / 2011$ \\
\hline 5. & Mei & 1.328 .768 .457 & 26.921 .112 & $10 / 06 / 2011$ & $19 / 06 / 2011$ \\
\hline 6. & Juni & 1.693 .424 .807 & 34.742 .975 & $13 / 07 / 2011$ & $21 / 07 / 2011$ \\
\hline 7. & Juli & 1.150 .791 .630 & 46.296 .800 & $15 / 08 / 2011$ & $22 / 08 / 2011$ \\
\hline 8. & Agustus & 3.989 .146 .792 & 86.531 .064 & $18 / 09 / 2011$ & $20 / 09 / 2011$ \\
\hline 9 . & September & 333.920 .680 & 6.678 .401 & $11 / 10 / 2011$ & $18 / 10 / 2011$ \\
\hline 10. & Oktober & 920.086 .680 & \begin{tabular}{|l|l}
18.401 .733 \\
\end{tabular} & $08 / 11 / 2011$ & $22 / 11 / 2011$ \\
\hline 11. & November & 1.722 .462 .864 & 35.782 .709 & $08 / 12 / 2011$ & $19 / 12 / 2011$ \\
\hline \multirow[t]{2}{*}{12} & Desember & 1.617 .743 .350 & 32.354 .867 & $04 / 01 / 2011$ & $20 / 01 / 2012$ \\
\hline & Jumlah & 19.774 .074 .200 & 436.294 .540 & & \\
\hline
\end{tabular}

Sumber : Delta Group

Penyetoran dan Pelaporan PPh Pasal 4 ayat 2 periode 201:

\begin{tabular}{|c|c|c|c|c|c|}
\hline No & Bulan & DPP & $\begin{array}{c}\text { PPH Pasal } 4 \\
\text { ayat } 2 \text { atas } \\
\text { jasa } \\
\text { konstruksi }\end{array}$ & Tgl Setor & Keterangan \\
\hline 1. & Januari & 1.575 .276 .642 & 31.505 .533 & $19 / 02 / 2012$ & $20 / 02 / 2012$ \\
\hline 2. & Februari & 1.355 .004 .971 & 27.100 .099 & $09 / 03 / 2012$ & $15 / 03 / 2012$ \\
\hline 3. & Maret & 2.175 .429 .102 & 43.508 .582 & $04 / 04 / 2012$ & $25 / 04 / 2012$ \\
\hline 4. & April & 1.114 .022 .832 & 22.280 .457 & $13 / 05 / 2012$ & $26 / 05 / 2012$ \\
\hline 5. & Mei & 1.660 .411 .616 & 33.474 .923 & $11 / 06 / 2012$ & $14 / 06 / 2012$ \\
\hline 6. & Juni & 1.916 .274 .049 & 38.325 .481 & $05 / 07 / 2012$ & $19 / 07 / 2012$ \\
\hline 7. & Juli & 720.836 .429 & 14.416 .729 & $10 / 08 / 2012$ & $14 / 08 / 2012$ \\
\hline 8. & Agustus & 1.814 .988 .054 & 36.299 .761 & $07 / 09 / 2012$ & $19 / 09 / 2012$ \\
\hline 9. & September & 609.739 .158 & 12.194 .783 & $10 / 10 / 2012$ & $22 / 10 / 2012$ \\
\hline 10. & Oktober & 1.367 .870 .820 & 27.357 .536 & $05 / 11 / 2012$ & $14 / 11 / 2012$ \\
\hline
\end{tabular}




\begin{tabular}{|l|l|l|l|l|l|} 
11. & November & 1.066 .078 .780 & 21.321 .576 & $06 / 12 / 2012$ & $19 / 12 / 2012$ \\
\hline 12 & Desember & 233.214 .408 & 46.784 .288 & $06 / 01 / 2013$ & $18 / 01 / 2012$ \\
\hline Jumlah & 17.718 .146 .861 & 354.569 .748 & & \\
& & & & & \\
\hline
\end{tabular}

Sumber : Delta Group

Penyetoran dan Pelaporan Pajak

Penghasilan Pasal 4 ayat 2 periode 2013

\begin{tabular}{|c|c|c|c|c|c|}
\hline No & Bulan & $\overline{\mathrm{DPP}}$ & \begin{tabular}{|lll} 
PPH & Pasal \\
ayat & 2 atas jasa \\
konstruksi &
\end{tabular} & Tgl Setor & Keterangan \\
\hline 1. & Januari & 2.327 .578 .221 & 46.551 .564 & $14 / 02 / 2013$ & \begin{tabular}{|l}
$18 / 02 / 2013$ \\
\end{tabular} \\
\hline 2. & Februari & 2.262 .782 .651 & 45.255 .653 & $15 / 03 / 2013$ & $20 / 03 / 2013$ \\
\hline 3. & Maret & \begin{tabular}{|l|}
933.728 .035 \\
\end{tabular} & \begin{tabular}{|l|}
18.674 .561 \\
\end{tabular} & $12 / 04 / 2013$ & $19 / 04 / 2013$ \\
\hline 4. & April & 1.660 .293 .506 & 33.205 .870 & $11 / 05 / 2013$ & $17 / 05 / 2013$ \\
\hline 5. & Mei & 1.606 .424 .819 & 32.128 .496 & $07 / 06 / 2013$ & $20 / 06 / 2013$ \\
\hline 6. & Juni & \begin{tabular}{|l}
1.313 .189 .147 \\
\end{tabular} & 26.263 .783 & $12 / 07 / 2013$ & $16 / 07 / 2013$ \\
\hline 7. & Juli & 1.478 .329 .153 & 29.566 .583 & $03 / 08 / 2013$ & $20 / 08 / 2013$ \\
\hline 8. & Agustus & \begin{tabular}{|l|}
1.319 .082 .594 \\
\end{tabular} & 26.381 .652 & $10 / 09 / 2013$ & $28 / 09 / 2013$ \\
\hline 9. & September & 1.952 .871 .079 & 39.057 .422 & $11 / 10 / 2013$ & $22 / 10 / 2013$ \\
\hline 10. & Oktober & 1.274 .937 .069 & 25.498 .741 & $07 / 11 / 2013$ & 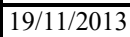 \\
\hline 11. & November & 1.332 .496 .757 & 26.649 .935 & $10 / 12 / 2013$ & $18 / 12 / 2013$ \\
\hline 12 & Desember & 1.447 .632 .928 & 28.952 .659 & $18 / 01 / 2014$ & $21 / 01 / 2013$ \\
\hline & Jumlah & \begin{tabular}{|l|}
18.909 .345 .957 \\
\end{tabular} & 378.186 .919 & & \\
\hline
\end{tabular}

Sumber : Delta Group 


\section{Penyetoran Pajak Penghasilan Pasal 4}

ayat 2 periode 2011

\begin{tabular}{|c|c|c|c|c|c|}
\hline No & Bulan & DPP & $\begin{array}{c}\text { PPH Pasal } 4 \\
\text { ayat } 2 \text { atas } \\
\text { jasa konstruksi }\end{array}$ & Tgl Setor & Keterangan \\
\hline 1. & Januari & 1.061 .215 .033 & 24.603 .322 & $03 / 02 / 2011$ & Tidak telat \\
\hline 2. & Februari & 1.943 .213 .470 & 40.181 .349 & $04 / 03 / 2011$ & Tidak telat \\
\hline 3. & Maret & 2.230 .462 .924 & 47.710 .292 & $11 / 04 / 2011$ & Telat 1 hari \\
\hline 4. & April & 1.782 .838 .173 & 36.089 .916 & $09 / 05 / 2011$ & Tidak telat \\
\hline 5. & Mei & 1.328 .768 .457 & 26.921 .112 & $10 / 06 / 2011$ & Tidak telat \\
\hline 6. & Juni & 1.693 .424 .807 & 34.742 .975 & $13 / 07 / 2011$ & Telat 3 hari \\
\hline 7. & Juli & 1.150 .791 .630 & 46.296 .800 & $15 / 08 / 2011$ & Telat 5 hari \\
\hline 8. & Agustus & 3.989 .146 .792 & 86.531 .064 & $18 / 09 / 2011$ & Telat 8 hari \\
\hline 9. & September & 333.920 .680 & 6.678 .401 & $11 / 10 / 2011$ & Telat 1 hari \\
\hline 10. & Oktober & 920.086 .680 & 18.401 .733 & $08 / 11 / 2011$ & Tidak telat \\
\hline 11. & November & 1.722 .462 .864 & 35.782 .709 & $08 / 12 / 2011$ & Tidak telat \\
\hline 12 & Desember & 1.617 .743 .350 & 32.354 .867 & $04 / 01 / 2011$ & Tidak telat \\
\hline & Jumlah & 19.774 .074 .200 & 436.294 .540 & & \\
\hline
\end{tabular}

Sumber : Delta Group

Berdasarkan tabel 4.6 dapat diketahui bahwa penyetoran Pajak penghasilan Pasal 4 ayat 2 atas jasa konstruksi pada Delta Kahuripan ada sebanyak empat kali penyetoran pajak yang belum sesuai dengan ketentuan perundangan yaitu pada Masa Maret 2011 di setor pada tanggal 11 april 2011 yang seharusnya paling telat disetorkan pada tanggal 10 april 2011, pada masa Juni 2011 disetor pada tanggal 13 Juli 2011 yang seharusnya paling telat di setorkan pada tanggal 10 Juli 2011, pada masa Juli 2011 disetor pada tanggal 15 Agustus 2011 yang seharusnya paling telat disetorkan pada tanggal 10 Agustus 2011, Pada masa September 2011 disetor pada tanggal 11 Oktober 2011 yang seharusnya di setorkan paling telat pada tanggal 10 Oktober 2011. 


\section{Penyetoran Pajak Penghasilan Pasal 4}

ayat 2 periode 2012

\begin{tabular}{|c|c|c|c|c|c|}
\hline No & Bulan & DPP & $\begin{array}{l}\text { PPH Pasal } 4 \\
\text { ayat } 2 \text { atas } \\
\text { jasa } \\
\text { konstruksi }\end{array}$ & Tgl Setor & Keterangan \\
\hline 1. & Januari & 1.575 .276 .642 & 31.505 .533 & $19 / 02 / 2012$ & Telat 9 hari \\
\hline 2. & Februari & 1.355 .004 .971 & 27.100 .099 & $09 / 03 / 2012$ & Tidak telat \\
\hline 3. & Maret & 2.175 .429 .102 & 43.508 .582 & $04 / 04 / 2012$ & Tidak telat \\
\hline 4. & April & 1.114 .022 .832 & 22.280 .457 & $13 / 05 / 2012$ & Telat 3 hari \\
\hline 5. & Mei & 1.660 .411 .616 & 33.474 .923 & $11 / 06 / 2012$ & Telat 1 hari \\
\hline 6. & Juni & 1.916 .274 .049 & 38.325 .481 & $05 / 07 / 2012$ & Tidak telat \\
\hline 7. & Juli & 720.836 .429 & 14.416 .729 & $10 / 08 / 2012$ & Tidak telat \\
\hline 8. & Agustus & 1.814 .988 .054 & 36.299 .761 & $07 / 09 / 2012$ & Tidak telat \\
\hline 9. & September & 609.739 .158 & 12.194 .783 & $10 / 10 / 2012$ & Tidak telat \\
\hline 10. & Oktober & 1.367 .870 .820 & 27.357 .536 & $05 / 11 / 2012$ & Tidak telat \\
\hline 11. & November & 1.066 .078 .780 & 21.321 .576 & $06 / 12 / 2012$ & Tidak telat \\
\hline 12 & Desember & 233.214 .408 & 46.784 .288 & $06 / 01 / 2013$ & Tidak telat \\
\hline & Jumlah & 17.718 .146 .861 & 354.569 .748 & & \\
\hline
\end{tabular}

Sumber : Delta Group

Berdasarkan tabel 4.7 dapat diketahui bahwa penyetoran Pajak Penghasilan Pasal 4 ayat 2 atas jasa konstruksi pada Delta kahuripan ada sebanyak tiga kali penyetoran pajak yang belum sesuai dengan ketentuan perundangan pada Masa pajak Januari 2012 yaitu disetor pada tanggal 19 Februari 2012 seharusnya paling telat di setorkan pada tanggal 10 Februari 2012, Masa Pajak April 2012 yaitu disetor pada tanggal 13 Mei 2012 seharusnya paling telat disetorkan pada tanggal 10 Mei 2012 dan Masa Pajak Mei disetorkan pada tanggal 11 Juni 2012 seharusnya paling telat disetorkan pada tanggal 10 Juni 2012. 
Penyetoran Pajak Penghasilan Pasal 4 ayat 2 periode 2013

\begin{tabular}{|c|c|c|c|c|c|}
\hline No & Bulan & DPP & $\begin{array}{l}\text { PPH Pasal } 4 \\
\text { ayat } 2 \text { atas jasa } \\
\text { konstruksi }\end{array}$ & Tgl Setor & Keterangan \\
\hline 1. & Januari & 2.327 .578 .221 & 46.551 .564 & $14 / 02 / 2013$ & Telat 4 hari \\
\hline 2. & Februari & 2.262 .782 .651 & 45.255 .653 & $15 / 03 / 2013$ & Telat 5 hari \\
\hline 3. & Maret & 933.728 .035 & 18.674 .561 & $12 / 04 / 2013$ & Telat 2 hari \\
\hline 4. & April & 1.660 .293 .506 & 33.205 .870 & $11 / 05 / 2013$ & Telat 1 hari \\
\hline 5. & Mei & 1.606 .424 .819 & 32.128 .496 & $07 / 06 / 2013$ & Tidak telat \\
\hline 6. & Juni & 1.313 .189 .147 & 26.263 .783 & $12 / 07 / 2013$ & Telat 2 hari \\
\hline 7. & Juli & 1.478 .329 .153 & 29.566 .583 & $03 / 08 / 2013$ & Tidak telat \\
\hline 8. & Agustus & 1.319 .082 .594 & 26.381 .652 & $10 / 09 / 2013$ & Tidak telat \\
\hline 9. & September & 1.952 .871 .079 & 39.057 .422 & $11 / 10 / 2013$ & Telat 1 hari \\
\hline 10. & Oktober & 1.274 .937 .069 & 25.498 .741 & $07 / 11 / 2013$ & Tidak telat \\
\hline 11. & November & 1.332 .496 .757 & 26.649 .935 & $10 / 12 / 2013$ & Tidak telat \\
\hline 12 & Desember & 1.447 .632 .928 & 28.952 .659 & $18 / 01 / 2014$ & Telat 8 hari \\
\hline & Jumlah & 18.909 .345 .957 & 378.186 .919 & & \\
\hline
\end{tabular}

Sumber : Delta Group

Berdasarkan tabel 4.8 dapat diketahui bahwa penyetoran Pajak Penghasilan Pasal 4 ayat 2 atas jasa konstruksi pada Delta Kahuripan ada sebanyak 7 kali penyetoran pajak yang belum sesuai dengan ketentuan perundangan yaitu Pada Masa Januari yaitu disetor pada tanggal 14 Februari 2013 seharusnya paling telat disetorkan pada tanggal 10 Februari 2013, Pada Masa Februari yaitu disetor pada tanggal 15 Maret 2013 seharusnya paling telat disetorkan pada tanggal 10 Maret 2013, Pada Masa Maret yaitu disetor pada tanggal 12 April 2013 seharusnya paling telat disetorkan pada tanggal 10 April 2013, Pada Masa April 2013 yaitu disetor pada tanggal 11 Mei 2013 seharusnya paling telat disetorkan pada tanggal 10 Mei 2013, Pada Masa Juni 2013 yaitu disetor pada tanggal 12 Juli 2013 seharusnya paling telat disetorkan pada tanggal 10 Juli 2013, Pada Masa September 2013 yaitu disetor pada tanggal 11 Oktober 2013 seharusnya paling telat disetorkan pada tanggal 10 Oktober 2013 dan Pada Masa Desember 2013 yaitu disetor pada tanggal 18 Januari 2014 seharusnya paling telat disetorkan pada tanggal 10 Januari 2014. 


\section{Pelaporan Pajak Penghasilan Pasal 4 ayat 2 atas Jasa Konstruksi pada DELTA GROUP}

Pph Final jasa konstruksi dilakukan bersamaan dengan pelaporan pph final lainnya (seperti pemotongan Pph final sewa tanah atau bangunan, deviden, dan sebagainya ). Pelaporan menggunakan formulir SPT Masa Pajak Penghasilan Pasal 4 ayat 2 kode formulir F.1.1.32.04 dan disampaikan ke Kantor Pelayanan pajak tempat pemotong Pajak Penghasilan terdaftar. Pelaporan harus dilakukan paling lambat tanggal 20 bulan berikutnya.

\section{Pelaporan Pajak Penghasilan Pasal 4 ayat 2 periode 2011}

\begin{tabular}{|c|c|c|c|c|c|}
\hline No & Bulan & $\overline{\mathrm{DPP}}$ & $\begin{array}{l}\text { PPH Pasal } 4 \\
\text { ayat } 2 \text { atas } \\
\text { jasa konstruksi }\end{array}$ & Tgl Lapor & Keterangan \\
\hline 1. & Januari & 1.061 .215 .033 & 24.603 .322 & $18-02-2011$ & Tidak telat \\
\hline 2. & Februari & 1.943 .213 .470 & 40.181 .349 & $14-03-2011$ & Tidak telat \\
\hline 3. & Maret & 2.230 .462 .924 & 47.710 .292 & $20-04-2011$ & Tidak telat \\
\hline 4. & April & 1.782 .838 .173 & 36.089 .916 & $16-05-2011$ & Tidak telat \\
\hline 5. & Mei & 1.328 .768 .457 & 26.921 .112 & 19-06-2011 & Tidak telat \\
\hline 6. & Juni & 1.693 .424 .807 & 34.742 .975 & $21-07-2011$ & Telat 1 hari \\
\hline 7. & Juli & 1.150 .791 .630 & 46.296 .800 & $22-08-2011$ & Telat 2 hari \\
\hline 8. & Agustus & 3.989 .146 .792 & 86.531 .064 & $20-09-2011$ & Tidak telat \\
\hline 9. & September & 333.920 .680 & 6.678 .401 & $18-10-2011$ & Tidak telat \\
\hline 10. & Oktober & 920.086 .680 & 18.401 .733 & $22-11-2011$ & Telat 2 hari \\
\hline 11. & November & 1.722 .462 .864 & 35.782 .709 & $19-12-2011$ & Tidak telat \\
\hline 12 & Desember & 1.617 .743 .350 & 32.354 .867 & $20-01-2012$ & Tidak telat \\
\hline & Jumlah & 19.774 .074 .200 & 436.294 .540 & & \\
\hline
\end{tabular}

Berdasarkan tabel 4.9 dapat diketahui bahwa pelaporan Pajak penghasilan Pasal 4 ayat 2 atas jasa konstruksi pada Delta Kahuripan ada sebanyak tiga kali pelaporan pajak yang belum sesuai dengan ketentuan perundangan yaitu Masa pajak Juni yaitu di lapor pada tanggal 21 juli 2011 yang seharusnya batas akhir pelaporannya adalah pada tanggal 20 juli 2011, Masa Pajak Juli 2011 yaitu dilapor pada tanggal 22 Agustus 2011 yang seharusnya batas akhir pelaporannya yaitu pada tanggal 20 Agustus 2011, Masa pajak Oktober 2011 yaitu pelaporannya dilakukan pada tanggal 22 November 2011 yang seharusnya batas akhir pelaporannya yaitu pada tanggal 20 November 2011. 


\section{Pelaporan Pajak Penghasilan Pasal 4 ayat}

\section{2 periode 2012}

\begin{tabular}{|c|c|c|c|c|c|}
\hline No & Bulan & DPP & $\begin{array}{l}\text { PPH } \quad \text { Pasal } 4 \\
\text { ayat } 2 \text { atas } \\
\text { jasa konstruksi }\end{array}$ & Tgl Lapor & Keterangan \\
\hline 1. & Januari & 1.575 .276 .642 & 31.505 .533 & $20-02-2012$ & Tidak telat \\
\hline 2. & Februari & 1.355 .004 .971 & 27.100 .099 & $15-03-2012$ & Tidak telat \\
\hline 3. & Maret & 2.175 .429 .102 & 43.508 .582 & $25-04-2012$ & Telat 5 hari \\
\hline 4. & April & 1.114 .022 .832 & 22.280 .457 & $26-05-2012$ & Telat 6 hari \\
\hline 5. & Mei & 1.660 .411 .616 & 33.474 .923 & 14-06-2012 & Tidak telat \\
\hline 6. & Juni & 1.916 .274 .049 & 38.325 .481 & 19-07-2012 & Tidak telat \\
\hline 7. & Juli & 720.836 .429 & 14.416 .729 & 14-08-2012 & Tidak telat \\
\hline 8. & Agustus & 1.814 .988 .054 & 36.299 .761 & 19-09-2012 & Tidak telat \\
\hline 9. & September & 609.739 .158 & 12.194 .783 & $22-10-2012$ & Telat 2 hari \\
\hline 10. & Oktober & 1.367 .870 .820 & 27.357 .536 & 14-11-2012 & Tidak telat \\
\hline 11. & November & 1.066 .078 .780 & 21.321 .576 & 19-12-2012 & Tidak telat \\
\hline 12 & Desember & 233.214 .408 & 46.784 .288 & 18-01-2013 & Tidak telat \\
\hline & Jumlah & 17.718 .146 .861 & 354.569 .748 & & \\
\hline
\end{tabular}

Sumber : Delta Group

Berdasarkan tabel 4.10 dapat diketahui bahwa pelaporan Pajak penghasilan Pasal 4 ayat 2 atas jasa konstruksi pada Delta Kahuripan ada sebanyak 3 kali pelaporan pajak yang belum sesuai dengan ketentuan perundangan yaitu pada Masa Pajak Maret yaitu di lapor pada tanggal 25 April 2012 yang seharusnya batas akhir pelaporannya adalah pada tanggal 20 April 2012, Masa pajak April 2012 yaitu dilapor pada tanggal 26 Mei 2012 yang seharusnya batas akhir pelaporannya adalah pada tanggal 20 Mei 2012, Masa pajak September 2012 yaitu dilapor pada tanggal 22 Oktober 2012 yang seharusnya batas akhir pelaporannya adalah pada tanggal 20 Oktober 2012. 


\section{Pelaporan Pajak Penghasilan Pasal 4 ayat 2 periode 2013}

\begin{tabular}{|c|l|l|l|l|l|}
\hline No & Bulan & DPP & PPH Pasal 4 & Tgl Lapor & Keterangan \\
ayat 2 atas & & \\
jasa & & & \\
konstruksi & & \\
\hline 1. & Januari & 2.327 .578 .221 & 46.551 .564 & $18-0202013$ & Tidak telat \\
\hline 2. & Februari & 2.262 .782 .651 & 45.255 .653 & $20-03-2013$ & Tidak telat \\
\hline 3. & Maret & 933.728 .035 & 18.674 .561 & $19-04-2013$ & Tidak telat \\
\hline 4. & April & 1.660 .293 .506 & 33.205 .870 & $17-05-2013$ & Tidak telat \\
\hline 5. & Mei & 1.606 .424 .819 & 32.128 .496 & $20-06-2013$ & Tidak telat \\
\hline 6. & Juni & 1.313 .189 .147 & 26.263 .783 & $16-07-2013$ & Tidak telat \\
\hline 7. & Juli & 1.478 .329 .153 & 29.566 .583 & $20-08-2013$ & Tidak telat \\
\hline 8. & Agustus & 1.319 .082 .594 & 26.381 .652 & $28-09-2013$ & Telat 8 hari \\
\hline 9. & September & 1.952 .871 .079 & 39.057 .422 & $22-10-2013$ & Telat 2 hari \\
\hline 10. & Oktober & 1.274 .937 .069 & 25.498 .741 & $19-11-2013$ & Tidak telat \\
\hline 11. & November & 1.332 .496 .757 & 26.649 .935 & $18-12-2013$ & Tidak telat \\
\hline 12 & Desember & 1.447 .632 .928 & 28.952 .659 & $21-01-2013$ & Telat 1 hari \\
\hline & Jumlah & 18.909 .345 .957 & 378.186 .919 & & \\
\hline & & & & & \\
\hline
\end{tabular}

Sumber : Delta Group

Berdasarkan tabel 4.11 dapat diketahui bahwa pelaporan Pajak penghasilan Pasal 4 ayat 2 atas jasa konstruksi pada Delta Kahuripan ada sebanyak 3 kali pelaporan pajak yang belum sesuai dengan ketentuan perundangan yaitu pada Masa Pajak Agustus yaitu di lapor pada tanggal 28 September 2013 yang seharusnya batas akhir pelaporan yaitu tanggal 20 September 2013, Masa Pajak September yaitu dilapor pada tanggal 22 Oktober 2013 yang seharusnya batas akhir pelaporan yaitu tanggal 20 Oktober 2013, Masa Pajak Desember yaitu dilapor pada tanggal 21 Januari 2014 yang seharusnya paling telat dilapor pada tanggal 20 Januari 2014.

\section{Penerapan Pajak Penghasilan Pasal 4 ayat 2 atas Beban Pajak}

Beban Pajak di Delta Group lebih besar dari yang seharusnya di setor karena adanya kesalahan dalam penarapan tarif pajak dan adanya keterlambatan setor dan bayar. Setiap tahap pekerjaan yang telah diselesaikan,maka Delta kahuripan akan memotong PPh pasal 4 ayat 2 . Adapun besarnya tarif yangdipotong oleh pihak Delta Group adalah 2\% dari nilai Dasar 
Pengenaan Pajak bagi subcont yang sudah mempunyai Nomor pokok Wajib Pajak. Dan tarif 4\% dari nilai Dasar Pengenaan Pajak bagi subcont yang belum mempunyai Nomor pokok wajib Pajak.

\section{PENUTUP}

\section{Kesimpulan}

Setelah penulis mengadakan penelitian langsung pada DELTA GROUP maka penulis dapat mengambil kesimpulan, antara lain:

1. Untuk Penerapan penghitungan, penyetoran dan pelaporan pajak penghasilan pasal 4 ayat 2 atas jasa konstruksi pada Delta Group masih ditemukan kesalahan contonhya penerapan tarif pajak penghasilan pasal 4 ayat 2. Pelaksanaan konstruksi yang dilakukan penyedia jasa yang berkualifikasi usaha menengah dan besar dikenakan tarif 3\% dan bersifat final. Akan tetapi, pada kenyataan Delta Group masih dikenakan tarif sebesar $2 \%$ atas jasa pelaksanaan konstruksi, penyetorannya juga masih banyak keterlambatan dan begitu pun dengan pelaporannya masih banyak keterlambatan dalam pelaporan pajaknya.

2. Untuk kesesuaian Penghitungan, penyetoran dan pelaporan pajak penghasilan pasal 4 ayat 2 atas proyek jasa konstruksi pada Delta Group adalah masih belum sesuai dengan PMK. Untuk Pajak penghasilan pasal 4 ayat 2 atas jasa konstruksi yang telah di potong oleh Delta Group dengan sample PT.DELTA KAHURIPAN tahun 2011 sebesar Rp. 436.294.540,- , tahun 2012 sebesar Rp. 354.569.748,- , tahun 2013 sebesar Rp. 378.186.919,- atau seluruhnya sebesar Rp. 1.169.051.207,-. Sedangkan pajak penghasilan yang seharusnya dipotong sesuai dengan UU.No.40 Tahun 2009 selama tahun 2011 adalah sebesar Rp.437.046.700,- , tahun 2012 sebesar Rp. 355.645.396,- , dan tahun 2013 sebesar Rp. 424.830.031,-, atau seluruhnyasebesarRp. 1.217.22.127,. Dari hasil perbandingan perhitungan tersebut dapat diketahui selisih perhitungan sehingga status pajak kurang bayar. Adapun besarnya pajak kurang bayar yang harus disetor oleh Delta Group untuk tahun 2011 adalah sebesar Rp. 752.160,- , tahun 2012 adalah sebesar Rp. 1.075.648,--, tahun 2013 adalah sebesar Rp. 46.643.112,-, atau seluruhnya jumlah pajak kurang bayar sebesar Rp. 48.470.920,-. Untuk Penyetoran 
yang di lakukan oleh Delta Group mengenai Pajak Penghasilan Pasal 4 ayat 2 belum dilakukan secara konsisten dan sesuai dengan aturan perpajakan yang ada yaitu sesuai dengan pasal 3 PMK Nomor 184/PMK.03.2007 yaitu paling telat tanggal 10 bulan berilkutnya setelah di terimanya pembayaran Untuk Pelaporan yang di lakukan oleh Delta Group mengenai Pajak Penghasilan Pasal 4 ayat 2 belum di lakukan secara konsisten yaitu paling telat tanggal 20 bulan berikutnya setelah di terimanya pembayaran imbalan jasa konstruksi, Dan jika tanggal 20 itu jatuh pada hari libur, termasuk hari sabtu maupun libur nasional, maka pelaporan SPT Masa dapat dilakukan pada hari kerja berikutnya.

3. Pembayaran dan Pelaporan yang telat akan mempengaruhi Beban Pajak Delta Group itu sendiri karena jika laporan itu telat dalam pembayarannya maupun pelaporan nya akan di kenakan sanksi administrasi sebesar 2\% dari dasar pengenaan pajak tiap bulannya selama 24 bulan. Dan sanksi administrasi tersebut akan diketahui oleh Delta Group setelah adanya pemeriksaan pajak dan pihak kantor pelayanan pajak akan mengeluarkan surat tagihan pajak.

\section{Saran}

Dari Kesimpulan yang telah penulis kemukakan, maka penulis memberikan saran kepada Delta Group untuk menjadi bahan masukan dalam mengambil kebijakan untuk menjadi bahan masukan dalam mengambil kebijakan yang diperlukan.Berikut beberapa masukan yang dapat penulis berikan adalah sebagai berikut:

1. Delta Group sebaiknya membuat list pengenaan tarif pajak untuk setiap subcont yang akan di potong pajak penghasilan pasal 4 ayat 2 nya agar tidak ada kesalahan dalam penerapan tarif dan agar penerapan tarif sesuai dengan klasifikasi usaha yang akan dipotong.

2. Delta Group harus tepat waku dalam menyetorkan Pajak penghasilan Pasal 4 ayat 2 atas jasa konstruksi dan melaporkannya dalam SPT Masa sebelum lewat batas waktu penyetoran dan pelaporan pajaknya sehingga terhindar dari sanksi keterlambatan pelaporan pajaknya 
3. Delta Group harus segera membayar pajak kurang bayar atas penghasilan dari usaha jasa konstruksi sebelum diterbitkannya Surat Ketetapan Pajak Kurang Bayar oleh Ditjen Pajak yang dapat mengakibatkan perusahaan dikenakan sanksi administrasi berupa bunga.

4. Delta Group sebaiknya melakukan pengisian laporan Pajak penghasilan pasal 4 ayat 2 menggunakan software atau aplikasi pajak yang sudah disediakan dari Kantor Pelayanan Pajak ( KPP) sehingga tidak perlu menggunakan penghitungan Pajak Penghasilan Pasal 4 ayat 2 secara manual pada saat pengisian SPT Masa sehingga Perhitungan Pajak Penghasilan Pasal 4 ayat 2 nilainya tepat dan benar.

\section{DAFTAR PUSTAKA}

Ajimat, “Metodologi Penelitian”, 2013.

Arikunto, “Metodologi Penelitian", 2002.

Gustiawan, Uwon, "Pedoman Praktis Ketentuan Umum dan Tata cara perpajakan", PT Gramedia Widiasarana Indonesia, Jakarta, 2007.

Husein, "Metode Penelitian”, 2008.

Kamus Besar Bahasa Indonesia, PT Media Pustaka Phoenix, Jakarta, 2005.

Mardiasmo, "Perpajakan”, Edisi revisi, Andi Offset, Yogyakarta, 2011. ,’Perpajakan”, Edisi revisi, Andi Offset, Yogyakarta, 2013.

Nazir, Mohammad, "Metode Penelitian", Ghalia Indonesia, Bogor, 2011.

Peraturan Menteri Keuangan nomor: 187/PMK.03/2008 tentang Tata cara pemotongan, penyetoran, peraturan dan penatausahaan pajak penghasilan dari usaha jasa konstruksi.

Peraturan Menteri Keuangan nomor: 243/PMK.03/2008 tentang Perubahan kedua atas keputusan menteri keuangan nomor 635/KMK.04/1994 tentang pelaksanaan pembayaran pajak penghasilan atas penghasilan dari pengalihan ha katas tanah dan atau bangunan.

Resmi, Siti, "Perpajakan Teori dan Kasus", Edisi 7, Salemba Empat, Yogyakarta, 2013.

Ridwan, “Metode dan Teknik Menyusun Proposal Penelitian”, Alfabeta, Bandung, 2004.

Rusdi, Muhammad, "PPH pajak penghasilan", PT Indeks Kelompok Gramedia, Jakarta, 2006. 
Sugiyono, "Metode Penelitian Kuantitatif Kualitatif dan R\&D", CV Alfabeta, Bandung, 2012.

Sukrisno, Agus. dkk. (2007) “Akuntansi Pajak”. Jakarta: Salemba Empat.

Undang-Undang Nomor 28 Tahun 2007, "Tentang Ketentuan Umum dan Tata Cara Perpajakan”.

Undang-Undang Republik Indonesia Nomor 18 Tahun 2000 Ps I angka 5, 302/KMK.04/1989 , "Pengertian Jasa Kena Pajak”.

Waluyo, "Perpajakan Indonesia", Edisi IX, Salemba Empat, Jakarta, 2010.

,"Perpajakan Indonesia",Edisi revisi,Salemba Empat,Jakarta,2011.

Yuniardi, Rendy Adotya, 2004, “Akuntansi Perpajakan Terapan”, Edisi Revisi, PT. Gramedia Widiasarana, Jakarta.

http://tax-center.pajak.go.id/tkb/pphpasal4(2).htm (diakses pada tanggal 16 april 2015 pukul 14.00)

http://www.pajak.net/info/tata_cara_bayar_pelaporan_pph.htm (diakses pada tanggal 14 april 2015 pukul 17.00)

http://www.pajak.go.id/dmdocuments/PER-2-2011.pdf( diakses pada tanggal 15 april 2015 pukul 13.00)

http://pajaktaxes.blogspot.com/pengusaha-kecil.html( diakses pada tanggal 13 april 2015 pukul 15.00) 